\title{
AS FAMÍLIAS SIMULTÂNEAS E A (DES)NECESSÁRIA INTERFERÊNCIA DO PODER PÚBLICO NAS RELAÇÕES PRIVADAS: UMA ANÁLISE À LUZ DO PEDIDO DE PROVIDÊNCIAS No 0001459.08.2016.2.00.0000 FEITO AO CONSELHO NACIONAL DE JUSTIÇA
}

\author{
Bruna Barbieri Waquim ${ }^{1}$ \\ José Guimarães Mendes Neto ${ }^{2}$
}

\begin{abstract}
RESUMO: O presente artigo teve por finalidade discutir o teor do Pedido de Providências ${ }^{\circ}$ 0001459.08.2016.2.00.0000, formulado pelo Instituto de Advogados de São Paulo ao Conselho Nacional de Justiça, recentemente julgado no sentido de proibir o registro de escrituras públicas de uniões poliafetivas. Adotando as metodologias de levantamento bibliográfico e análise documental, o artigo debate três pontos principais: a possibilidade jurídica da constituição de famílias paralelas e a produção de efeitos no campo do Direito de Família; o papel regulamentador do Conselho Nacional de Justiça e a função das Serventias Extrajudiciais de Registro nas relações privadas e, por fim, os limites da ingerência do Poder Público na autonomia da vontade que representa o pilar do Direito Privado e, em especial, do Direito de Família. Conclui-se que a procedência do pedido de providências $\mathrm{n}^{\circ}$ 0001459.08.2016.2.00.0000 pelo CNJ não só desrespeita princípios constitucionais como o próprio Estado Democrático de Direito, ao tolher as individualidades de voluntariamente escolherem o arranjo familiar que bem lhes convir.
\end{abstract}

Palavras-Chave: Autonomia Privada; Conselho Nacional de Justiça; Direito de Família; Pedido de Providências $\mathrm{N}^{\mathrm{o}}$ 0001459.08.2016.2.00.0000; Uniões Poliafetivas.

\section{THE SIMULTANEOUS FAMILIES AND THE (UN)NECESSARY INTERFERENCE OF THE PUBLIC POWER IN PRIVATE RELATIONS: AN ANALYSIS UNDER THE LIGHT OF THE REQUEST FOR PROVISIONS NUMBER 0001459.08.2016.2.00.0000 MADE TO THE NATIONAL COUNCIL OF JUSTICE IN BRAZIL}

\begin{abstract}
The purpose of this article was to discuss the content of the Request for Provisions number 0001459.08.2016.2.00.0000, formulated by the São Paulo Lawyers Institute to the National Council of Justice, recently judged to prohibit the registration of public deeds of multiple unions. Adopting methodologies of bibliographical survey and documentary analysis, the article discusses three main points: the legal possibility of the constitution of parallel families and the production of effects in the field of Family Law; the regulatory role of the National Council of Justice and the role of the

\footnotetext{
${ }^{1}$ Doutoranda em Direito pelo Centro Universitário de Brasília - UniCEUB/DF. Mestre em Direito e Instituições do Sistema da Justiça pela Universidade Federal do Maranhão - UFMA. Professora do Curso de Direito da Unidade de Ensino Superior Dom Bosco - UNDB. Assessora Jurídica no Tribunal de Justiça do Estado do Maranhão. Email: bu_barbieri@yahoo.com.br

${ }^{2}$ Mestrando em Direito Constitucional pelo Instituto Brasiliense de Direito Público - IDP/DF. Especialista em Direito Eleitoral pela Pontifícia Universidade Católica de Minas Gerais - PUC/MG e em Direito Penal Econômico pela Universidade de Coimbra. Advogado. Email: guimaraesmneto@hotmail.com
} 
Extrajudicial Registry Services in private relations and, finally, the limits of the interference of the Public Power in the autonomy of the will that represents the pillar of Private Law and, in particular, the Family Law. It is concluded that the judgment of the request of measures no. 0001459.08.2016.2.00.0000 by the CNJ not only disrespects constitutional principles as the Democratic State of Law itself, by preventing individuals from voluntarily choosing the family arrangement that better suits them.

Keywords: Private autonomy. National Council of Justice. Family law. Request for Provisions $\mathrm{n}^{\circ}$ 0001459.08.2016.2.00.0000. Parallel unions.

\section{INTRODUÇÃO}

Notícia recentemente divulgada nos canais de comunicação jurídicos reacendeu um debate latente na sociedade brasileira: é possível constituir relações simultâneas conjugais, as chamadas "famílias paralelas"?

Em resumo, o Conselho Nacional de Justiça foi formalmente instado a se manifestar sobre a prática de titulares de Serventias de Notas que realizam lavratura de escrituras declaratórias de uniões poliafetivas e, como ato inicial, a Corregedora-Geral de Justiça recomendou às serventias que não mais as realizem, até a conclusão do Pedido de Providências $\mathrm{n}^{\circ}$ 0001459.08.2016.2.00.0000. Tal providência preliminar foi criticada por grande parcela de juristas, por representar ingerência indevida do Poder Público sobre as relações privadas, especialmente considerando a finalidade do registro de uma escritura pública, que é de apenas formalizar uma declaração de vontade.

O caso se reveste de especial relevância acadêmica pois permite questionar se poderia o Estado (Poder Público) proibir os particulares de constituir uniões conjugais paralelas - como se afigura do caso do Pedido de Providências acima comentado. Antes, porém, deve ser problematizada a própria possibilidade do reconhecimento de efeitos jurídicos às famílias simultâneas, bem como quais os limites da atuação do Conselho Nacional de Justiça sobre os particulares.

Por isso, na primeira seção, serão analisadas as transformações constitucionais do conceito de família que inseriram o princípio da pluralidade das formas de família no ordenamento jurídico pátrio, cuja diretriz pode autorizar a possibilidade jurídica da constituição e reconhecimento de efeitos jurídicos às chamadas "uniões paralelas".

A seguir, será contextualizado o papel do Conselho Nacional de Justiça como fiscal da atuação dos serviços judiciais e extrajudiciais e como isto reverbera na vida dos cidadãos, 
especialmente na regulamentação das atividades cartorárias, bem como será melhor relatado o teor do Pedido de Providências n ${ }^{\circ}$ 0001459.08.2016.2.00.0000, que nele tramita.

Por fim, será discutido sobre quais balizas jurídicas é possível e legítimo - ou se se torna impossível e ilegítimo - o Poder Público se imiscuir na autonomia privada de seus cidadãos e proibir-lhe a livre disposição de sua liberdade afetiva.

Fazendo-se uso do método indutivo, portanto, serão movimentadas as ferramentas metodológicas da análise documental e do levantamento bibliográfico para, a partir do estudo de caso, debater cientificamente os liames da ingerência do Poder Público sobre a vida dos particulares, quanto à constituição de famílias simultâneas.

\section{AS UNIÕES PARALELAS E O DEBATE SOBRE SUA POSSIBILIDADE JURÍDICA}

O reconhecimento jurídico de uniões conjugais simultâneas ainda é um dos temas mais controversos no Direito Civil brasileiro, mesmo sendo a ocorrência de relacionamentos paralelos algo tão antigo quanto a própria história humana.

Nas sociedades mesopotâmicas, por exemplo, uma série de circunstâncias permitiam a bigamia, como a esterilidade da esposa, caso, em um prazo de até sete anos após o casamento, não gerasse descendentes. Na Grécia Clássica, como a concepção básica que regia a união entre um homem e uma mulher era a procriação, os homens podiam encontrar prazer sexual com as prostitutas e atenção especial com as concubinas. Na China antiga, com o casamento arranjado, as filhas de famílias pobres eram vendidas para famílias ricas, e os homens poderiam ter vários concubinos e/ou várias concubinas - geralmente adolescentes - após a primeira esposa, mas o adultério era inaceitável (GUEDES, 2010).

Estudos de demografia e história da família demonstram que, nas sociedades latinoamericanas, há a peculiaridade da proliferação de relações extramatrimoniais e nascidos ocorridos fora do sacramento do matrimônio, que escapavam ao controle apertado da Igreja Católica pós-tridentina. As raízes do concubinato e da ilegitimidade dos filhos teriam ligação com questões de raça, cor e condição social dos indivíduos. Especialmente no Brasil Colonial, a família uma e indissolúvel, legitimada pelo sacramento do matrimônio, estava estabelecida apenas na camada dos grandes proprietários brancos (SCOTT, 1998).

Em Portugal, em meados dos séculos XIV e XV, a expressão utilizada para se referir ao que hoje se conhece como concubina era "barregã", termo utilizado no livro V das 
Ordenações Afonsina, que trata da prática qualificando-a como criminosa e prescrevendo uma grande quantidade de interdições às barregãs. Nas Ordenações Afonsinas, três eram as modalidades de barregania (concubinato): a com homens solteiros, a com homens casados e a com homens religioso (SILVA, 2011). A legislação portuguesa tem destaque no presente trabalho pois, após o período de Colonização e Impérios, a primeira codificação genuinamente brasileira, no âmbito do Direito Civil, só se deu com a promulgação da Lei $\mathrm{n}^{\circ} 3.071$ de $^{\circ}{ }^{\mathrm{o}}$ de janeiro de 1916, intitulada "Código Civil dos Estados Unidos do Brasil”.

Cruz e Waquim (2014) esclarecem que uma das pedras fundamentais do sistema tradicional consolidado pelo Código Civil de 1916 era a obrigação de que os casais contraíssem casamento (pagando, assim, os encargos devidos aos templos - Igreja - e aos cartórios - ao Estado), pois sem essa solenidade, a união não era abençoada por Deus nem protegida pelos Poderes Públicos. Porém nem todos podiam arcar com os custos de um casamento, gerando um sem número de pessoas que conviviam em concubinato, não por serem impedidos de se casar (as chamadas relações adulterinas), mas porque não suportavam as despesas de um matrimônio ou simplesmente porque não queriam submeter-se a esse rito. Muitos, ainda, sofriam com as consequências de casamentos arranjados pelos chefes de suas famílias, pois o casamento, sendo indissolúvel, não permitia que esse casal, arrependido do enlace, buscasse a constituição de novas famílias.

A indissolubilidade do casamento foi expressa e literalmente assegurada pelas Constituições brasileiras de 1934, 1937, 1946, 1967, até que a Constituição de 1988 trouxe uma nova redação ao conceito constitucional de família. Ao estabelecer, em redação concisa - porém não menos significativa - que "A família, base da sociedade, tem especial proteção do Estado" (artigo 226), a Constituição da República de 1988 inovou o paradigma do conceito jurídico de "família", afastando-a de fórmulas e modelos pré-estabelecidos (como o era a fórmula restritiva do "a família é formada pelo casamento indissolúvel") e abrindo espaço para que a definição do que seja "família" seja construída conforme a dinâmica social.

Assim, com a Constituição da República de 1988 e o posterior Código Civil de 2002, as relações civis foram repersonalizadas ${ }^{3}$ e o Direito de Família passou a ter, como pedra

\footnotetext{
3 Na lição de Lobo (2004), “A família, ao converter-se em espaço de realização da afetividade humana e da dignidade cada um de seus membros, marca o deslocamento da função econômica-política-religiosaprocracional para essa nova função. Essas linhas de tendência enquadram-se no fenômeno jurídico-social denominado repersonalização das relações civis, que valoriza o interesse da pessoa humana mais do que suas relações patrimoniais. $\mathrm{O}$ anacronismo da legislação sobre família revelou-se em plenitude com o despontar dos novos paradigmas das entidades familiares".
} 


\section{AS FAMÍLIAS SIMULTÂNEAS E A (DES)NECESSÁRIA INTERFERÊNCIA DO PODER PÚBLICO \\ NAS RELAÇÕES PRIVADAS: UMA ANÁLISE À LUZ DO PEDIDO DE PROVIDÊNCIAS № 0001459.08.2016.2.00.0000 FEITO AO CONSELHO NACIONAL DE JUSTIÇA}

angular, a orientação dos princípios da igualdade, da dignidade e da pluralidade familiar, passando-se a reconhecer outras modalidades de família que não apenas a derivada do casamento civil ou religioso com efeitos civis. O artigo 226, portanto, traz a família como categoria, sendo espécies a família formada pelo casamento civil $\left(\S 1^{\circ}\right)$, pelo casamento religioso $\left(\S 2^{\circ}\right)$, pela união estável $\left(\S 3^{\circ}\right)$, pela monoparentalidade $\left(\S 4^{\circ}\right)$ e, uma vez afastada pela CF88 a cláusula de exclusão de que família era somente aquela formada pela via do "casamento indissolúvel", a vida cotidiana demonstra a existência de outras famílias que não foram contempladas pelo artigo 226: a família anaparental, a família singular, a família homoafetiva e, objeto deste trabalho, a família paralela.

Nesse cenário de pluralidade das formas de família, é importante atentar que o artigo $5^{\circ}$, II, da Lei Maria da Penha (Lei n ${ }^{\circ} 11.340 / 2006$ ) afirma que se considera como entidade familiar a união de pessoas que se consideram aparentadas por ato de vontade, o que reforça a positivação de um conceito de família no sentido da estruturação psíquica de seus membros (VECCHIATTI, 2014), ou seja, o desejo de conviver e ser reconhecido como família.

É dizer: o divisor de águas trazido pela Constituição de 1988 ao Direito de Família é a autorização jurídica para que os indivíduos exerçam sua autonomia privada afetiva, de forma responsável, mas livre. E sob os auspícios do princípio da pluralidade das formas de família, que escolham a modalidade de composição que melhor lhes aprouver.

Voltando o olhar ao tempo presente, em pesquisa exploratória realizada no dia 07 de fevereiro de 2018, no Portal Jusbrasil, na seção "Jurisprudência", a utilização do termo chave "concubinato" apontou 17.451 (dezessete mil, quatrocentos e cinquenta e um) resultados, o que parece indicar 17.451 ementas de julgamentos que contenham tal assunto; destes, 1.084 (mil e oitenta e quatro) apenas no último ano. Alterando a chave de pesquisa para "união estável paralela", com o uso de aspas, encontrou-se 447 (quatrocentos e quarenta e sete) resultados.

Tais números são um indicativo de que, independente da ausência de previsão legal expressa sobre as chamadas "familias simultâneas" (RUZYK, 2005) "poliamorismo" (GAGLIANO, 2008), "relações simultâneas conjugais" (WAQUIM, 2010) ou “união estável poliafetiva" (VECCHIATTI, 2012), tal constituição é um fato que se apresenta diuturnamente aos Tribunais, em busca da solução aos conflitos de interesses daí decorrentes.

\footnotetext{
4 Consulta realizada por meio do portal Jusbrasil (https://www.jusbrasil.com.br/jurisprudencia).
} 
O STJ, ao ser instado para se pronunciar sobre a possibilidade jurídica da existência de "uniões estáveis paralelas", tem consagrado o entendimento da inadmissibilidade de seu reconhecimento, sob o argumento de que "se uma relação afetiva de convivência for caracterizada como união estável, as outras concomitantes, quando muito, poderão ser enquadradas como concubinato (ou sociedade de fato)" (BRASIL, 2014).

Em particular, no julgamento do REsp n ${ }^{\circ} 1.348 .458$ - MG, a Ministra Andrighi assentou na ementa do julgado que "Embora não seja expressamente referida na legislação pertinente, como requisito para configuração da união estável, a fidelidade está ínsita ao próprio dever de respeito e lealdade entre os companheiros"(BRASIL, 2014). Prosseguiu a relatora afirmando que Uma sociedade que apresenta como elemento estrutural a monogamia não pode atenuar o dever de fidelidade - que integra o conceito de lealdade e respeito mútuo - para o fim de inserir no âmbito do Direito de Família relações afetivas paralelas e, por consequência, desleais, sem descurar que o núcleo familiar contemporâneo tem como escopo a busca da realização de seus integrantes, vale dizer, a busca da felicidade” (BRASIL, 2014).

O julgado paradigmático, porém, ressalta que, ao analisar as lides que apresentam paralelismo afetivo, deve o juiz, atento às peculiaridades multifacetadas apresentadas em cada caso, decidir com base na dignidade da pessoa humana, na solidariedade, na afetividade, na busca da felicidade, na liberdade, na igualdade, bem assim, com redobrada atenção ao primado da monogamia, com os pés fincados no princípio da eticidade (BRASIL, 2014).

A improcedência da pretensão de reconhecimento jurídico da união estável paralela, em suma, foi justificada em virtude de "Na hipótese, a recorrente não logrou êxito em demonstrar, nos termos da legislação vigente, a existência da união estável com o recorrido, podendo, no entanto, pleitear, em processo próprio, o reconhecimento de uma eventual uma sociedade de fato entre eles"(BRASIL, 2014).

De fato e de direito, para o reconhecimento de uma união estável, o ordenamento jurídico exige como requisitos para "o homem e a mulher" a "convivência pública, contínua e duradoura e estabelecida com o objetivo de constituição de família" (caput do artigo 1.723 do Código Civil), não se configurando união estável “se ocorrerem os impedimentos do art. 1.521; não se aplicando a incidência do inciso VI no caso de a pessoa casada se achar separada de fato ou judicialmente" ( $\$ 1^{\circ}$ do mesmo artigo alhures citado).

Seria atecnia, portanto, denominar-se a constituição de famílias paralelas como "uniões estáveis paralelas", eis que, dentro da categoria "Família", a espécie "união estável" exige o dever de lealdade e a ausência de impedimentos para o casamento. As famílias paralelas 
são uma espécie autônoma de entidade familiar, previstas no artigo 1.727 do Código Civil que as define como "concubinato", sob a seguinte disposição: "As relações não eventuais entre o homem e a mulher, impedidos de casar, constituem concubinato".

É importante que se destaque que inexiste proibição legal à constituição de concubinato; o próprio Código Civil, ao defini-lo, o entende como relações "não eventuais", denotando certa estabilidade e distinguindo-o das meras relações adulterinas e incestuosas. Porém, não foram regulados os efeitos jurídicos derivados da constituição de um concubinato, havendo apenas algumas disposições patrimoniais, como, por exemplo, a previsão do artigo 1.708 do Código Civil, que estabelece que "Com o casamento, a união estável ou o concubinato do credor, cessa o dever de prestar alimentos."

Por isso, é legítimo defender a possibilidade jurídica da constituição de famílias paralelas - nome que vem sendo utilizado em substituição ao termo pejorativo "concubinato" - eis que inexiste vedação jurídica expressa para sua constituição. E, se o primado do Direito Privado é que aos particulares é dado fazer tudo aquilo que não se lhes é proibido em lei, afigura-se incabível - e quiçá injusto - a própria vedação ao exercício de sua liberdade afetiva.

Este fato dialoga com a necessidade contemporânea de um conceito ético-político incompleto de justiça, tal como exposto por Braga (2014), por meio do qual os agentes que coprotagonizam a correção empírica do que é justo, diante das carências legislativas, possam atender às necessidades reais:

O conceito ético-político incompleto de justiça insiste numa cosmo visão em que não há prevalência absoluta, apriorística do bem sobre o justo. A ideia de uma vida boa, tal como apresentada por cosmovisões religioso-metafísica, no império da moral teológica em relação à moral deontológica, cai por terra, à medida que nas sociedades contemporâneas não é mais possível identificar coesão quanto à estima e à capacidade de acreditar e também de concretizar um único ideal de vida boa. A vida boa transmutou-se para a vida concreta, cujo qualificativo reside na pluralidade e na utilização emancipadora da subjetividade (BRAGA, 2014, p.123).

A argumentação jurídica presentemente desenvolvida, porém, não é admitida pacificamente na doutrina brasileira nem tem pautado a atuação das instituições e entidades do sistema da justiça, como será debatido no item a seguir, na investigação sobre o teor do Pedido de providências n ${ }^{\circ}$ 0001459.08.2016.2.00.0000, em tramitação junto ao Conselho Nacional de Justiça.

3 O CNJ E A PROIBIÇÃO DE ESCRITURAÇÃO DE UNIÕES PARALELAS 
Este capítulo objetiva analisar o pedido de providências $\mathrm{n}^{\circ}$ 0001459.08.2016.2.00.0000 feito junto ao CNJ. No entanto, se iniciará tratando sobre o papel do CNJ e o debate que envolve a sua constitucionalidade. Além disso, se tratará também sobre a função das escrituras públicas, a fim de pavimentar o iter argumentativo necessário à solução do problema de pesquisa ora posto.

No período pós Segunda Guerra Mundial, a supremacia legislativa deixa de ser vista como predominante, consoante a maior responsabilidade que o Estado passa a ter para com os direitos fundamentais, em especial, no quesito da efetividade dos mesmos. Assim sendo, diversos foram os países que transferiram a ótica de incorporação e efetividade dos direitos e garantias fundamentais do legislativo para o poder Judiciário (DE OLIVEIRA, 2012)

Nesse contexto e considerando o momento brasileiro pós Constituição de 1988, o poder Judiciário passa a ter forte ascensão e, por consequência, passa a ser bem mais inserido nas agendas de debates acadêmicos e legislativos.

Deste modo, evidencia-se que o crescimento institucional do Judiciário acaba fazendo com que o mesmo deixe de ser um simples departamento técnico e torne-se também um corpo institucional político (CAMARGO, 2017).

Em síntese, seriam três as grandes causas para sua ascensão, quais sejam: 1) reconhecimento de que o Poder Judiciário fortalecido e com independência seria de suma importância para a garantia e proteção da democracia e dos direitos fundamentais; 2) crença universal de que a democracia representativa apresenta falhas e não seria capaz de atender a todas as demandas societárias, razão pela qual o Judiciário se faz mais importante, ou seja, se faz necessário para efetivação de algumas daquelas demandas que a democracia representativa passa a ser incapaz de atender e conciliar os interesses; 3) constatação de que a política majoritária que se desenvolve no legislativo não é capaz de produzir consensos em matéria de extrema importância e, por consequência, geram disputas que precisam ser resolvidas pelo Poder Judiciário (BARROSO, 2017).

Por estas causas o Judiciário passou a ocupar um espaço de forte proeminência. $\mathrm{O}$ Brasil, por exemplo, em função de sua Constituição abrangente e com um sistema de controle de constitucionalidade que permite a declaração de inconstitucionalidade por todos os juízes, bem como o fato de um controle de constitucionalidade que permite um acesso direto a Suprema Corte para declaração de inconstitucionalidade de determinada lei, acabou por alimentar não só a ascensão institucional, mas principalmente a judicialização de questões que deveriam ser prioritariamente decididas em âmbito de parlamento e não de tribunal (BARROSO, 2015). 


\title{
AS FAMÍLIAS SIMULTÂNEAS E A (DES)NECESSÁRIA INTERFERÊNCIA DO PODER PÚBLICO NAS RELAÇÕES PRIVADAS: UMA ANÁLISE À LUZ DO PEDIDO DE PROVIDÊNCIAS № 0001459.08.2016.2.00.0000 FEITO AO CONSELHO NACIONAL DE JUSTIÇA
}

Quanto a isso, Dworkin (2000) defende essa confiança em favor do Poder Judiciário ao mencionar que este seria responsável pela primeira palavra, uma vez considerando ser esta com alto teor de qualificação o que, por sua vez, não necessitaria de interpretação nova a posterior a ser proferida. No entanto, apesar da defesa, admite a possibilidade de erros e que, quando ocorridos, caberia a sociedade civil, por meio da desobediência, preservar a integridade do direito.

No entanto, excessiva transmissão de confiança ao Poder Judiciário também pode provocar abusos. Neste sentido, Waldron (2014, p. 13) defende que a supremacia judicial acabaria por retirar do povo e de seus representantes, o amplo poder de deliberações sobre questões essenciais para a direção das instituições, enfraquecendo a própria democracia.

Em razão disso que Maus (2000, p. 184) se importa em discutir de que forma a "atividade do controle normativo judicial, tal como configurada no modelo de Estado constitucional moderno, teria contribuído para a perda da racionalidade jurídica ou mesmo para racionalizações autoritárias", isto é, no que toca a atividade judicial dos tribunais constitucionais passou-se a pairar receios por sua expansão autocrática, piorada com o fato da inexistência de desenvolvimento de qualquer forma de controle. Em paralelo a essa expansão do Judiciário tem-se também a receptividade concordante pela população, chegando, inclusive, a ganhar contornos de veneração. Quanto a isso, observa-se a seguinte lição:

\begin{abstract}
A expectativa de que a Justiça possa funcionar como instância moral não se manifesta somente em pressuposições de cláusulas legais, mas também na permanência de uma certa confiança popular. Mesmo quem procura evitar ao máximo a precipitada interferência paterna nos conflitos que ocorrem nos aposentos infantis, seguindo critérios antiautoritárias de educação, favorece com maior obviedade aquela mesma estrutura autoritária quando se trata da condução de conflitos sociais. A Justiça aparece então como uma instituição que, sob a perspectiva de um terceiro neutro, auxilia as partes envolvidas em conflitos de interesses e situações concretas, por meio de uma decisão objetiva, imparcial e, portanto, justa. (MAUS, 2000, p.90)
\end{abstract}

Todavia, quando o Poder Judiciário eleva-se a uma condição de instância supra moral da sociedade passa, por sua vez, a ficar alheio a mecanismos de controle social, ou seja, resta nítida a regressão a valores não democráticos. Por esse motivo que Maus questiona se não estaria a Justiça “em sua atual conformação, além de substituta do imperador, o próprio monarca substituído?" (MAUS, 2000, p.187).

Diante disso, fortaleceu-se a inquietação acerca do papel institucional a ser exercido pelo Judiciário. A este não pode ser dado ilimitados poderes para substituir aquelas instâncias que precipuamente são responsáveis pelas decisões políticas tradicionais. Nesse contexto que surge a necessidade de uma reforma no poder Judiciário. Perpassado esses debates o parlamento 
brasileiro então aprova a Emenda Constitucional n 45/2004, que inova em vários aspectos, principalmente com a criação do CNJ.

Assim sendo, o CNJ surge durante todo esse contexto de forte crescimento, independência e representatividade política do Poder Judiciário. Surge, em geral, como um órgão de composição mista para fins de melhor promover a comunicação do Judiciário para com a sociedade como um todo. Além disso, o compete fazer o planejamento institucional, a reivindicação de compromissos ou verbas, a apresentação de relatórios com estatísticas, o zelo pelo acesso à justiça universalizado e, principalmente, a punição das condutas desviantes (BARROSO, 2005).

Segundo o Ministro Cesar Peluso (BRASIL, 2005) seriam duas as atribuições do CNJ, quais sejam: “(a) o controle da atividade administrativa e financeira do Judiciário; e (b) o controle ético-disciplinar de seus membros". No entanto, a criação deste órgão não ficou alheio a questionamentos quanto a sua constitucionalidade. Tanto assim foi que a Associação dos Magistrados Brasileiros sustentou sua inconstitucionalidade (ADIn $\mathrm{n}^{\circ}$ 3.367-DF) deduzindo: a) violação do princípio da separação de Poderes; b) violação do princípio federativo; c) inconveniência constitucional da medida (BARROSO, 2005).

Do julgamento da mencionada ADIn no 3.367-DF, o Supremo entendeu que sob o prisma da Constituição Federal e do sistema de separação de poderes adotado, a criação do CNJ em nada o ofenderia, pois, o que constituinte originalmente projetou foi um esqueleto institucional onde o Poder Judiciário teria garantida sua independência e autonomia orgânica, financeira e administrativa, entretanto, temperou ao também adjudicar outras atribuições de controle recíproco. Além disso, a estrutura pensada é a de órgão próprio do Judiciário onde sua composição é por maioria preenchida sem a interferência dos outros Poderes. No mais, ao Conselho não seria concedido qualquer poder de reavaliar as decisões dada pelos magistrados, portanto, não há qualquer interferência na função típica do Poder Judiciário, motivo que comprova o fiel zelo pela autonomia e independência deste e, por consequência, pelo próprio princípio da separação dos poderes (BARROSO, 2005).

No que toca a atribuição do Conselho quanto "ao cumprimento dos deveres funcionais dos juízes", defende-se como conquista democrática do Estado a construção de mecanismos que responsabiliza todo e qualquer agente público - no caso os magistrados - por atos que inobservem as obrigações funcionais para boa prestação jurisdicional. Por sua vez, a simples existência de corregedorias não vem produzindo eficiência necessária, razão pela qual a criação de um órgão como o CNJ acaba por direcionar para uma saída a essa imperfeição. Além disso, 
sua composição por membros externos ao Judiciário conclama por uma erradicação de um forte a sanguinário mal do Brasil: o corporativismo (BARROSO, 2005).

Quanto ao argumento de que a criação do CNJ viola o pacto federativo, o Supremo também não deu razão a esse posicionamento. Segundo o Ministro Cesar Peluso a criação do Conselho em nada altera o quadro constitucional do Judiciário brasileiro, assim como possui a particularidade de órgão federal, isto é, representativo do Estado unitário e não, portanto, como órgão vinculado a União. Ademais, sua própria composição permite visualizar a não violação do princípio federativo, pois contempla tanto a esfera federativa da União como dos Estadosmembros, bem como permite a indicação de um cidadão pelo Senado Federal o que, por seu turno, também demonstra ser uma vontade pela participação dos Estados (BRASIL, 2005).

Por último, a ADIn no 3.367-DF ainda sustentou a inconstitucionalidade do CNJ em razão da inconveniência constitucional da medida, ou seja, sob o argumento de que o Conselho criado tinha as mesmas competências já atribuídas ao Conselho de Justiça Federal e ao Conselho Superior da Justiça do Trabalho o que, por sua vez, caracterizaria um conflito de competência. Acontece que a questão da (in)conveniência da inovação originada pela $\mathrm{EC} \mathrm{n}^{\circ} 45$ não é parâmetro para controle de constitucionalidade, tampouco constitui alguma cláusula pétrea capaz de invalidar emenda constitucional. Ou seja, "é imperativo distinguir bem os espaços da crítica política e da atividade jurídica de controle de constitucionalidade", portanto, ao Judiciário não cabe substituir juízo político tomado em amplo e democrático espaço (BARROSO, 2005).

Todavia, o CNJ não está liberto de limitações. Pelo contrário. O artigo 103-B, §4, inciso II da Constituição Federal Brasileira deixa claro que ao CNJ compete o zelo pela autonomia do Poder Judiciário e pelo cumprimento do Estatuto da Magistratura, bem como pode expedir atos regulamentares ou recomendar providências.

Enquanto primeira limitação, tem-se o fato de que o $\mathrm{CNJ}$ não pode alcançar, com suas atribuições, o Supremo Tribunal Federal (BRASIL, 2005). Foi dito também que compete ao $\mathrm{CNJ}$ recomendar providências. Este pedido é uma classe processual onde propostas e sugestões são feitas ao CNJ para que maior eficácia possa ser dada ao Poder Judiciário. Inclusive, esta é a única classe em que pode ser distribuída tanto para a Corregedoria Nacional de Justiça quanto para os Conselheiros, a ficar na dependência apenas da matéria sobre a qual os autos se refere (CONSELHO NACIONAL DE JUSTIÇA, sn). 
Por sequência, quanto a expedição de atos regulamentares, a compreensão a ser tida é a de que ao CNJ não é permitido inovar no plano jurídico de maneira originária, mas tão somente regulamentar quaisquer disposições normativas legais que estejam conexas com a autonomia do Judiciário e o cumprimento de seu Estatuto. Portanto, a produção normativa do CNJ é apenas secundária. Exige-se, assim, que seja vedado ao CNJ a edição de resolução dispondo sobre a questão ou desconstituindo, revisando ou fixando prazo de para regularização de ato administrativo com o intuito de criar orientações e inovações pelo próprio CNJ (TAVARES, 2009).

E é sobre essa ótica, de que não assiste ao CNJ o poder de inovar no plano jurídico, que deve ser analisada a atuação do Conselho no julgamento do Pedido de Providências $n^{\circ}$ 0001459.08.2016.2.00.0000, a fim de debater a hipótese da legitimidade ou não da resposta conferida pelo órgão ao referido pedido.

Tecendo breve relato para a compreensão da divergência, a Associação de Direito de Família e das Sucessões - ADFAS fez um pedido cautelar de providências, e no mérito requereu a manutenção da liminar e a regulamentação da questão, para fins de que fosse proibida a lavratura de escrituras públicas de uniões paralelas pelas respectivas serventias extrajudiciais do Brasil (BRASIL, 2016).

O pedido aduziu que as lavraturas de escrituras públicas de uniões paralelas seriam inconstitucionais, pois careciam de eficácia jurídica, bem como violaria “i) princípios familiares básicos, ii) regras constitucionais sobre família, iii) dignidade da pessoa humana, iv) das leis civis e v) da moral e dos costumes brasileiros". Aduz ainda que a tentativa de ampliar o conceito do $\S 3$ do artigo 226 da Constituição Federal seria um "engodo" e um "equívoco", pois o texto constitucional seria expresso ao limitar a constituição de união estável a duas pessoas (BRASIL, 2016).

A título preliminar a Ministra Nancy Andrighi decidiu intimar todas as Corregedorias de Justiça dos Estados Membros para cientificar as serventias extrajudiciais de Notas sobre o referido pedido de providências em tramitação, bem como recomendasse o aguardo da conclusão do mesmo para lavrar, ou não, novas escrituras que declarem uniões paralelas (BRASIL, 2016). A despeito de inexistir proibição expressa na recomendação preliminar do Conselho, é sabido que "os notários são muito cautelosos e temem contrariar orientações das Corregedorias que supervisionam os seus atos. Assim, é possível que a recomendação seja recebida por muitos como uma proibição" (IBDFAM, 2017). 
Até que, na sessão do dia 26 de junho de 2018, concluiu-se o julgamento do referido Pedido de Providências. O placar final da votação foi de 7 votos pela proibição do registro de escrituras públicas de uniões poliafetivas, nos termos do voto do ministro relator, João Otávio de Noronha; 5 votos acompanhando a divergência parcial do conselheiro Aloysio Corrêa para permitir o registro, mas sem a equiparação com os direitos da união estável, e um voto totalmente divergente, do conselheiro Luciano Frota, pela improcedência do pedido (IBDFAM, 2018). No entanto, há que se refletir, inicialmente, sobre a natureza das escrituras públicas, para que seja possível perquirir sobre a legalidade e legitimidade da vedação de sua lavratura, especialmente no caso assentado.

Sabe-se que as escrituras públicas são documentos onde se atesta como verdade para todos os efeitos tudo que ali tiver contido. Em razão disso, ao notário cabe: 1) a responsabilidade de esclarecer toda e qualquer dúvida dos envolvidos para que seja mantida na integridade a vontade dos mesmos; ali se manifeste na integridade a vontade dos mesmos; 2) observar a licitude do objeto; 3) identificar os envolvidos e suas capacidades; 4) assim como verificar o cumprimento das exigências tributárias. Deste modo, a escritura pública caracteriza-se como documento de fé pública que atesta, portanto, prova plena do que fora realizado (PADOIN, 2011).

Trata-se, assim, de um instrumento legitimado para o exercício da autonomia privada, que, segundo a clássica lição de Fachin (1988, p.56):

... está diretamente vinculada ao espaço que o universo jurídico reserva aos
particulares para disporem sobre seus interesses. Em verdade, a autonomia privada
tem um reconhecimento da ordem jurídica, na medida em que a própria lei confere
explicitamente o espaço em branco para que os particulares o preencham. Esse
reconhecimento decorre da aplicação de um critério de exclusão, pois os particulares
atuam nos espaços permitidos, isto é, não vedados pela ordem jurídica.

O interesse na lavratura de escrituras públicas reside justamente na possibilidade de formalizar a vontade das partes, permitindo a produção dos efeitos jurídicos decorrentes dessa declaração. Por isso, uma vez debatida favoravelmente a possibilidade jurídica da constituição de uniões poliafetivas no item anterior, é o momento de se questionar, como o será feito no item a seguir: poderia o Poder Público proibir os particulares de constituir uniões conjugais paralelas e de reconhecer a essa vontade efeitos jurídicos?

\section{4 É Legítimo AO PODER PÚBlico PROIBIR A FORMAÇÃo DE UNIÕES} PARALELAS?

Revista de Direito de Família e Sucessão | e-ISSN: 2526-0227 | Porto Alegre | v. 4 | n. 2 | p. 138 - 159 | Jul/Dez. 2018 
No contexto cada vez mais dinâmico da sociedade, uma característica que decorre da transformação da estrutura social no Brasil é a complexidade na qual se tornara as relações sociais. Os números de conflitos envolvendo pessoas e situações das mais diversas e inimagináveis crescem exponencialmente, o que, por sua vez, vem constantemente exigindo posicionamento dos atores jurídicos e políticos (FREITAS FILHO, 2009).

No contexto familiar, portanto, não diferentemente acontece. Por conta disso que sempre se exige do Direito uma constante atualização, uma vez que somente assim o mesmo estará e permanecerá em sintonia para com o fatidicamente vivido em comunidade.

Como já dito, as relações de família sofrem constantes adaptações e, dentre elas, a experiência das chamadas uniões paralelas ou famílias simultâneas vem se tornando cada vez mais frequente no mundo real e, por consequência, tem sido um desafio para a comunidade jurídica por exigir uma posição definitiva e pacificadora que solucione a demanda.

Repisando, as uniões paralelas são entendidas como aquelas relações afetivas onde um dos membros vive concomitantemente com mais de uma pessoa e onde há todo o cumprimento dos requisitos da entidade familiar, quais sejam: o afeto, a convivência e a intenção de formar uma família (FRISON, 2012).

A questão principal, portanto, está em saber se é cabível negar o reconhecimento dessas uniões pelo Poder Público. Se sim ou se não, e sobre quais pretextos argumentativos. No mais, saber se a monogamia seria um princípio é também de supra importância para solucionar a problemática que envolve o reconhecimento das uniões paralelas como entidades familiares.

Para alguns, a monogamia seria um princípio basilar das relações jurídicas da família, funcionando como uma força motriz legítima e moral das relações conjugais e amorosas. De outra sorte, há quem entenda exatamente o contrário, isto é, de que a pretensão de elevar monogamia ao patamar de princípio seria um mito e estaria alheia a qualquer fundamentação na Constituição brasileira, uma vez considerando a inexistência de menção, neste sentido, no texto legal (FRISON, 2012).

Há ainda o entendimento de que a monogamia seria um valor enraizado culturalmente pela Igreja Católica, quando da simbiose Estado-Igreja, que acabou construindo juridicamente a ideia de família e o que, por sua vez, deveria ser adotado enquanto padrão desejável. A razão seria para proteção da propriedade privada e castração de desejos (SOALHEIRO, 2013).

Sabe-se que os princípios surgem do direito natural. Todavia, com o advento do positivismo jurídico os mesmos passaram a adquirir normatividade jurídica, entretanto, em um 
patamar hierárquico secundarizado ao das regras, ou seja, apenas com a função de coibir o vazio normativo que o sistema fechado de regras poderia vir a ter. Todavia, com o pós positivismo, os princípios igualam-se hierarquicamente. Deixam o seu antigo caráter supletivo e passam a ter primazia tanto quanto as regras jurídicas (FERNANDES, 2015).

Segundo Roberto Freitas Filho (2009), por conta da mutabilidade da vida, a inserção de princípios, cláusulas gerais e conceitos jurídicos indeterminados se deram para permitir uma maior mobilidade ao aplicador e assim permitir que a aplicabilidade da norma seja possível não só para as relações pensadas quando do momento de sua positivação, mas também para as relações futuras e não inicialmente pensadas. Ou seja, são projetadas para o tempo presente e futuro.

Lembra Karl Larenz (1997) da dificuldade de aplicação destas normas abertas, bem como do erro que se constituiria achar que a aplicação destes tipos de normas se compreenderia com o procedimento da subsunção. Assim sendo, caracteristicamente, os princípios são: normas de alto grau de abstração, carecedoras de medidas concretizadoras, de caráter estruturante e fundamental no ordenamento jurídico, próximas da ideia de direito e de justiça e que formam a base das próprias regras. Não obstante estas, a que ganhou maior notoriedade foi a ideia Alexyana de que as regras seriam normas ao modo do tudo ou nada, da técnica da subsunção, enquanto os princípios seriam mandamentos de otimização a serem aplicados de acordo com a metodologia da ponderação (FERNANDES, 2015).

Por sua vez, Lavocat Galvão (2014), ao falar sobres as regras e os princípios, lembra que o intérprete ao se fundamentar exclusivamente neste último acaba por ter um espectro decisionista bem amplo o que aumenta sua liberdade de escolha. Teria apenas que se preocupar em direcionar ao ordenamento jurídico para não incorrer em deslegitimidade. Porém, por mais encantador que essa postura possa parecer, o perigo iminente é claro e nefasto, qual seja: uma vez considerando o amplo cargo princípiológico de nossa Constituição, saber o que será ou não concretizado desta sai do campo legislativo e se transfere eminentemente para o Judiciário. Isso se torna mais perigoso ainda quando a ideia neoconstitucional ainda defende a interpretação extensiva dos princípios.

Roberto Freitas Filho (2009, p.291) destaca que as normas jurídicas não são formuladas em uma linguagem que se aproxime da lógica matemática, mas sim em lógica natural, razão, portanto, que justifica a dificuldade de colocar um conteúdo de "sentido as normas” para inserção das mesmas como “premissa maior de um silogismo jurídico".

Revista de Direito de Família e Sucessão | e-ISSN: 2526-0227 | Porto Alegre | v. 4 | n. 2 | p. 138 - 159 | Jul/Dez. 2018 
No mais, menciona que a verdadeira distinção não seria entre princípios e regras, mas entre os princípios e as regras expressadas via cláusulas gerais de um lado e as regras casuísticas de outro. Ou seja, a diferença seria porque haveria princípios ou cláusulas gerais que usariam termos ou palavras avaliatórias, enquanto que nas regras casuísticas os termos ou palavras seriam descritivas (FREITAS FILHO, 2009).

Não obstante, defende-se aqui a posição de que a monogamia não é e nem deve ser observada como princípio. Primeiramente por não se enquadrar nas características mencionadas. Segundo porque resta claro que a monogamia é um valor de conduta moral, enraizado, culturalmente, no contexto familiar e que, portanto, não possui a possibilidade de se exigir judicialmente. Terceiro por conta de conduta de valor moral possuir raiz alto critério subjetiva e, assim, não se poder fomentar como fonte matriz de um ordenamento jurídico.

Deste modo, uma vez os sujeitos não escolhendo a monogamia como valor para seu arranjo familiar, então ao Estado não cabe interferir para forçar escolha diversa. Tal postura não só fere princípios como o da autonomia privada, da isonomia, do pluralismo familiar e o da dignidade da pessoa humana, como contraria a concepção de Estado Democrático de Direito (FRISON, 2012).

O limbo jurídico, no entanto, em que se encontram estas uniões de fato - que, como visto, são tão antigas quanto a própria história oficial do Brasil - tem autorizado o exercício do já citado afeto irresponsável, por meio do qual verdadeiras famílias são constituídas durante o esgotamento dos desígnios afetivo-sexuais de determinados parceiros que, após vivenciarem a simultaneidade, descartam as parceiras utilizando a própria natureza do paralelismo como subterfúgio ao desamparo (WAQUIM, 2010).

Portanto, não apenas preservar as escolhas de cada um, mas também proteger assistencialmente esse arranjo familiar é o que cabe ao Estado, haja vista que o domínio de decisão a ele não pertence.

O pluralismo familiar e, por consequência, a fática vivência das uniões paralelas não possui pretensão de transformar o matrimônio, mas de reconhecer que outros arranjos familiares existem. Desta forma igual proteção o Direito deve garantir, sem, portanto, hierarquizar qualquer um de seus tipos. No mais, não se pretende com isso se justificar a bigamia, mas encontrar soluções justas para realidades que se queira ou não estão acontecendo e vem sendo demandado manifestações aos tribunais do país (MARANHÃO, 2014).

Além do mais, sobre três aspectos o tema das uniões paralelas precisa ser esclarecido: sobre o aspecto penal, constitucional e administrativo. Primeiro, ao Estado não é possível, nem 


\section{AS FAMÍLIAS SIMULTÂNEAS E A (DES)NECESSÁRIA INTERFERÊNCIA DO PODER PÚBLICO NAS RELAÇÕES PRIVADAS: UMA ANÁLISE À LUZ DO PEDIDO DE PROVIDÊNCIAS № 0001459.08.2016.2.00.0000 FEITO AO CONSELHO NACIONAL DE JUSTIÇA}

permitido, ignorar proteção as famílias simultâneas, uma vez inexistindo qualquer mandamento legal que a equipare a bigamia ou mesmo a qualquer outra situação impeditiva, ainda que isso tenha por consequência a tri (ou mais) repartição dos direitos. Segundo, a omissão estatal seria inconstitucional, pois o Estado estaria se omitindo na validação de direitos fundamentais o que, por obvio, ocorre se uma família existente no plano dos fatos (as uniões paralelas) é esquecida pelo Poder Público (FERRARINI, 2010).

O que deve ser reconhecido é que não consta do ordenamento jurídico expressa proibição à constituição de famílias paralelas - reconhece-se apenas a lacuna na lei quanto aos efeitos a serem produzidos diante da sua configuração (WAQUIM, 2010).

Por último, quanto ao aspecto administrativo, se o CNJ é órgão próprio do Poder Judiciário logo também não a ele caberia incentivar a omissão e a inércia estatal quanto a uma realidade fática presente e que cada vez mais clama e precisa da proteção do Estado. De tal modo, o acolhimento do pedido de providências $n^{\circ}$ 0001459.08.2016.2.00.0000 pelo $\mathrm{CNJ}$ não só desrespeita princípios constitucionais como o próprio Estado Democrático de Direito. Tolhe as individualidades de voluntariamente escolherem o arranjo familiar que bem lhes convir.

Ainda que se argumente que a decisão do CNJ não "proíbe" a constituição de uniões paralelas e que, portanto, estariam as individualidades preservadas para o livre exercício da sua autonomia privada, por óbvio que negar a esta constituição a produção de efeitos jurídicos como nega a vedação de registro público ora debatida - é tornar invisível juridicamente esta forma de composição de família, deixando seus membros completamente desprotegidos na seara cível e previdenciária, entre outras.

Proibir a escrituração das uniões poliafetivas, assim, possui o mesmo efeito prático de proibir sua constituição, eis que aqueles que assim desejarem conviver em família, ficarão à margem do Direito, na invisibilidade que por muitas décadas sacrificou a mulher casada, os chamados filhos "bastardos" e as uniões homoafetivas.

Oportunas são as palavras de Rodrigo da Cunha Pereira (2018), refletindo sobre tal julgamento:

O Direito funciona como um sistema de limites e freios e é também um instrumento ideológico de inclusão e exclusão de pessoas no laço social. Ele sempre se pautou por uma moral religiosa e seus dogmas, para sustentar, inclusive relações de poder e de dominação. E agora, o CNJ repete fato histórico semelhante ao da ilegitimação de filhos. As uniões poliafetivas existem no mundo fático, mas não podem existir no jurídico. É como se dissesse: fechem os olhos para esta realidade pois ela afronta a moral e os bons costumes. Este importante órgão da justiça parece não querer enxergar que proibir de se lavrar escrituras de três ou mais pessoas vivendo juntas numa relação amorosa não vai fazer com que as pessoas deixem de viver desta forma. Obvio: a

Revista de Direito de Família e Sucessão | e-ISSN: 2526-0227 | Porto Alegre | v. 4 | n. 2 | p. 138 -159 | Jul/Dez. 2018 
escritura pública não cria o fato, mas tão somente registra a existência dele. E a família é da ordem da cultura, e não da natureza, por isto em constante mutação. Portanto, essas e outras formas de viver a conjugalidade sempre surgirão. Quem imaginava há 50 anos atrás que o Estado legitimaria o concubinato, que passou a se chamar união estável? Quem imaginaria há 10 anos, que as uniões homoafetivas sairiam da invisibilidade jurídica, e que seria possível uma pessoa ter o nome de mais de um pai e mãe em sua certidão de nascimento? Afasto o que não conheço / o que vem de outro sonho feliz de cidade. (Caetano Veloso)

Defende-se que ao Poder Público não é legítimo proibir a formação de uniões paralelas. Caberia, portanto, não só a proteção destas tanto no que toca ao reconhecimento quanto a atribuição de efeitos jurídicos concretos.

Tem que se ter a ideia de que o principal elemento de configuração de um arranjo familiar não é o comando legislativo, mas sim o afeto. Assim, não se pode negar o reconhecimento de uma família deliberadamente escolhida pelos envolvidos cuja maioridade e capacidade encontram-se claramente configurada (FRISON, 2012).

Todavia, importa-se o destaque para que, não obstante se defenda a proteção estatal quanto as uniões paralelas, não se defende, entretanto, que eventual suscitação no âmbito do Supremo Tribunal Federal, principalmente, via ADIn, deva vir a ser provida, sob pena de incurso nos mesmos equívocos ativistas como na decisão ao julgar a ADIn 4277 relativa as uniões homoafetivas.

Isto é, uma vez o debate chegando ao STF, cabe a este reconhecer e legitimar as uniões paralelas bem como garantir, via efeito aditivo a decisão, os efeitos jurídicos necessários a relação familiar, sejam eles de natureza previdenciária ou cível (ABBOUD, 2016, 715).

\section{CONSIDERAÇÕES FINAIS}

Como dito, o reconhecimento jurídico das uniões paralelas vem sendo um dos temas mais controversos no Direito Civil brasileiro, não obstante esta forma de relacionamento ser uma das mais antigas práticas da história humana. Nesse cenário que a pesquisa realizada se propôs a enfrentar o seguinte problema: ao Poder Público seria permitido proibir os particulares de constituírem uniões conjugais simultâneas?

Para tanto, partiu-se inicialmente da análise das transformações constitucionais do conceito de família e a consequente inserção do princípio da pluralidade das formas de família do ordenamento jurídico nacional, no qual, por sua vez, pode fundamentar a possibilidade jurídica de reconhecimento, bem como de constituição dos efeitos jurídicos as chamadas uniões paralelas. Restou claro que com a Constituição Federal de 1988, ao Direito de Família foi 
ofertado a autorização jurídica para que os indivíduos exerçam sua autonomia privada afetiva, sob a batuta do princípio da pluralidade das formas de família.

Em seguida, a finalidade se voltou para a análise do pedido de providências $n^{\circ}$ 0001459.08.2016.2.00.0000 feito junto ao CNJ. Para esse fim, iniciou-se tratando sobre o papel institucional do CNJ e todo o debate que o envolveu quanto a sua constitucionalidade, bem como sobre a função das escrituras públicas. Observou-se, desta análise, que ao Conselho Nacional de Justiça não cabe inovar no plano jurídico e é sobre essa perspectiva que o Pedido de Providências nº 0001459.08.2016.2.00.0000 deve ser observado. Além disso, as escrituras são instrumentos para o exercício da autonomia privada, portanto, o interesse na lavratura das mesmas consiste na possibilidade de formalização da vontade das partes.

Por fim, objetivou-se investigar se seria legítima e lícita (no aspecto penal, constitucional e administrativa) as iniciativas do Poder Público de proibir o reconhecimento jurídico de uniões paralelas.

Nesse contexto, defendeu-se pela possibilidade jurídica da constituição de uniões paralelas, uma vez que inexiste vedação jurídica expressa pela constituição, posto que aos particulares é permitido fazer aquilo que por lei não lhe é proibido.

Defendeu-se ainda que ao Poder Público não é legítimo proibir a formação de uniões paralelas, uma vez que para o arranjo familiar o que mais interessa não é o comando legislativo, mas sim o afeto. No mais alertou-se para que uma vez sustentado o debate no STF, a este caberia o reconhecimento e a legitimação das uniões paralelas bem como a garantia de seus efeitos jurídicos (cíveis e previdenciários) via efeito aditivo a decisão.

\section{REFERÊNCIAS}

ABBOUD, Georges. Processo constitucional brasileiro. São Paulo: Editora Revista dos Tribunais, 2016.

BARROSO, Luís Roberto. Palestra acerca dos papéis contramajoritário, representativo e iluminista, proferida na Conferência Internacional de Direito Constitucional, Brasília/DF, em 29 de maio de 2017.20 Disponível <https://m.youtube.com/watch?feature=youtu.be\&v=9Nt9-yZi8rs>. Acesso em: 08 jan. 2018.

Contramajoritário, representativo e iluminista: os papéis das cortes constitucionais nas democracias contemporâneas. 2015. Disponível em: <http://s.conjur.com.br/dl/notaspalestra-luis-robertobarroso.pdf>. Acesso em: 08 jan. 2018. 
Constitucionalidade e legitimidade da criação do Conselho Nacional de Justiça. 2005.

Disponível em: <http://www.migalhas.com.br/arquivo_artigo/luis_roberto1.htm>. Acesso em: 05 fev. 2018.

BRAGA, Luiz Felipe Nobre. Direito existencial das famílias: da dogmática à principiologia. Rio de Janeiro: Lumen Juris, 2014.

BRASIL. Supremo Tribunal Federal. Ação Direta de Inconstitucionalidade no 3.367-DF, Relator Ministro Cezar Peluso, Plenário, julgado 13/04/2005.

Conselho Nacional de Justiça. Pedido de Providências nº 0001459-08.2016.2.00.0000, Relatora Ministra Nancy Andrighi, julgado 13/04/2016.

Superior Tribunal de Justiça. Agravo Regimental no Agravo de Instrumento no 1130816 MG 2008/0260514-0, Relator: Ministro Vasco Della Giustina (desembargador convocado do TJ/RS), Data de Julgamento: 19/08/2010, T3 - Terceira Turma, Data de Publicação: DJe 27/08/2010.

Superior Tribunal de Justiça. Recurso Especial no 1348458 MG 2012/0070910-1, Relatora Ministra NANCY ANDRIGHI, Data de Julgamento: 08/05/2014, T3 - Terceira Turma, Data de Publicação: DJe 25/06/2014

CAMARGO, Margarida Lacombe; VIEIRA, José Ribas; SILVA, Diogo Bacha e. A vaquejada e o incipiente diálogo institucional: o difícil diálogo em meio a um constitucionalismo de conflito instaurado pela crise política. 2017. Disponível em: <https://jota.info/artigos/avaquejada-e-o-incipiente-dialogo-institucional-23062017>. Acesso em: 02 jan. 2018.

CONSELHO NACIONAL DE JUSTIÇA. Como acionar o CNJ?. Disponível em: http://www.cnj.jus.br/ouvidoria-page/como-peticionar-ao-cnj. Acesso em: 15 fev. 2018.

CRUZ, Monica da Silva. WAQUIM, Bruna Barbieri. A (curiosa) transformação legislativa do direito de família brasileiro. Revista dos Tribunais. Vol.944/2014. Jun./2014. São Paulo: Revista dos Tribunais.

DWORKIN, Ronald. Uma questão de princípio. Tradução: Luís Carlos Borges. São Paulo: Editora Martins Fontes. 2000.

DE OLIVEIRA, Leandro Correa. O judicial review permite um diálogo entre poderes. 2012. Disponível em: <http://www.conjur.com.br/2012-nov-23/leandro-oliveira-judicial-reviewpermite-dialogo-entre-poderes>. Acesso em: 15 fev. 2018.

FACHIN, Luiz Edson. Novo conceito de ato e negócio jurídico. Curitiba: Educa; Scientia et Labor, 1988.

FERRARINI, Letícia. Famílias simultâneas e seus efeitos jurídicos: pedaços da realidade em busca da dignidade. Porto Alegre: Editora Livraria do Advogado, 2010.

FERNANDES, Bernardo Gonçalves. Curso de direito constitucional. Salvador: Editora JusPODIVM. 2015. 
FREITAS FILHO, Roberto. Intervenção judicial nos contratos e aplicação dos princípios e cláusulas gerais. Porto Alegre: SAFE, 2009.

FRISON, Mayra Figueiredo. O pluralismo familiar e a mutação constante do formato de família: a constitucionalização do direito civil e dimensões do concubinato na promoção da dignidade da pessoa humana. 2012. 132 f. Dissertação (Mestrado em Direito) - Faculdade de Direito do Sul de Minas. Minas Gerais. Pouso Alegre. 2012.

GAGLIANO, Pablo Stolze. Direitos da(o) amante - na teoria e na prática (dos Tribunais). Revista IOB de Direito de Família, São Paulo, V.9, nº. 49, p. 51-61, ago. 2008

GALVÃO, Jorge Octávio Lavocat. O Neoconstitucionalismo e o fim do estado de direito. São Paulo: Saraiva, 2014.

GUEDES, Dilcio Dantas. Revisão histórica e psicossocial das ideologias sexuais e suas expressões. Rev. Mal-Estar Subj. [online]. 2010, vol.10, n.2, pp. 447-493 . Disponível em: $<$ http://pepsic.bvsalud.org/scielo.php?script=sci_arttext\&pid=S1518-

61482010000200005\&lng=pt\&nrm=iso>. Acesso em: 24 fev. 2018.

IBDFAM. CNJ recomenda aos cartórios que não façam escrituras de uniões poliafetivas. 2016. Notícia publicada no site do IBDFAM. Disponível em:

<http://www.ibdfam.org.br/noticias/5986 >. Acesso em: 24 fev. 2018.

Família poliafetiva e especialistas reagem à decisão do CNJ. 2018. Notícia publicada no site do IBDFAM. Disponível em: < http://www.ibdfam.org.br/noticias/6674>. Acesso em: 03 jul. 2018.

LARENZ, Karl. Metodologia da ciência do direito. $3^{\text {a }}$ edição. Lisboa: Fundação Calouste Gulbenkian, 1997, p. 299.

LÔBO, Paulo. A repersonalização das relações de família. Revista Jus Navigandi, ISSN 15184862, Teresina, ano 9, n. 307, 10 maio 2004. Disponível em: 〈https://jus.com.br/artigos/5201〉. Acesso em: 25 fev. 2018.

MARANHÃO. Tribunal de Justiça do Estado do Maranhão. Apelação Cível no 19048/2013 (728-90.2007.8.10.0115) - Rosário, Relator Desembargador Lourival de Jesus Serejo Sousa, Terceira Câmara Cível, julgado 10/07/2014.

MAUS, Ingeborg. Judiciário como superego da sociedade: o papel da atividade jurisprudencial na "sociedade órfã". Novos Estudos CEBRAP. No 58. Novembro, 2000.

PADOIN, Fabiana Fachinetto. Direito notarial e registral. Rio Grande do Sul: Editora Unijuí. 2011.

PEREIRA, Rodrigo da Cunha. Uniões poliafetivas, liberdade e Estado laico. 2018. Notícia publicada no site do CONJUR. Disponível em: <https://www.conjur.com.br/2018-jul01/unioes-poliafetivas-liberdade-estado-laico>. Acesso em: 03 jul. 2018.

Revista de Direito de Família e Sucessão | e-ISSN: 2526-0227 | Porto Alegre | v. 4 | n. 2 | p. 138-159 | Jul/Dez. 2018 
RUZYK, Carlos Eduardo Pianovski. Famílias simultâneas: da unidade codificada à pluralidade constitucional. Rio de Janeiro: Renovar, 2005.

SCOTT, Ana Silvia Volpi. Desvios morais nas duas margens do Atlântico: o concubinato no Minho e em Minas Gerais nos anos setecentos. Comunicação Livre, NEPS, Universidade do Minho, 1998. Disponível em: <http://www.cepesepublicacoes.pt/portal/pt/obras/populacao-esociedade/revista-populacao-e-sociedade-no-7/ >. Acesso em: 20 fev. 2018.

SILVA, Edlene Oliveira. "Quem chegar por último é a mulher do padre": as Cartas de Perdão de concubinas de padres na Baixa Idade Média portuguesa. Cadernos Pagu (37), julhodezembro de 2011:357-386. Disponível em: < http://www.scielo.br/scielo.php?pid=S0104$83332011000200015 \&$ script=sci_abstract $>$. Acesso em: 18 fev. 2018

SOALHEIRO, Luiza Helena Messias. Família paralela: uma análise à luz do pluralismo familiar. 2013. Disponível em: < http://www.conteudojuridico.com.br/artigo,familia-paralelauma-analise-a-luz-do-pluralismo-familiar,43622.html>. Acesso em 15 fev. 2018.

TAVARES, André Ramos. O conselho nacional de justiça e os limites de sua função regulamentadora. Biblioteca Digital Revista Brasileira de Estudos Constitucionais - RBEC, Belo Horizonte, ano 3, n. 9, jan. 2009.

VECCHIATTI, Paulo Roberto Iotti. União estável poliafetiva: breves considerações acerca de sua constitucionalidade. Revista Jus Navigandi, ISSN 1518-4862, Teresina, ano 17, n. 3395, 17 out. 2012. Disponível em: <https://jus.com.br/artigos/22830>. Acesso em: 24 fev. 2018.

Famílias paralelas e poliafetivas devem ser reconhecidas pelo Judiciário. Revista Consultor Jurídico, 5 de agosto de 2014. Disponível em: < https://www.conjur.com.br/2014ago-05/paulo-iotti-familias-paralelas-poliafetivas-reconhecidas>. Acesso em: 25 fev. 2018.

WALDRON, Jeremy. Judicial Review and Judicial Supremacy. New York University School of Law, Public Law \& Legal Theory Research Paper Series. Working Paper n. 14-57, November 2014.

WAQUIM, Bruna Barbieri. Relações simultâneas conjugais: o lugar da Outra no Direito de Família. São Luís: Café \& Lápis, 2010. 